\title{
PENGARUH STIMULAN ETEFON TERHADAP PRODUKSI DAN FISIOLOGI LATEKS BERBAGAI KLON IRR
}

\author{
Effect of Ethephon Stimulation on Yield and Latex Physiology \\ on Various IRR Clones \\ Eva HERLINAWATI* dan KUSWANHADI \\ Balai Penelitian Sembawa, Pusat Penelitian Karet \\ Jl. Palembang - Pangkalan Balai KM 29 PO BOX 1127 \\ Palembang 30001 Sumatera Selatan \\ *Email : eva_herlinawati@yahoo.com
}

Diterima : 16 Januari 2018 / Disetujui : 27 Februari 2018

\begin{abstract}
Stimulation have been commonly used by private companies to optimize labour and profits. Application of stimulant can increase latex flow and cell metabolism. However, ethephon stimulation is not matched with plant potency. Stimulation in exploitation system should follow the typology of clone. The purpose of this study was to know the optimal frequency of stimulation in each clone by considering physiological condition and plant health. The experiment was carried out at Sembawa Research Center from 2011 to 2014, using IRR 24, IRR 41, IRR 100, IRR 105, and IRR 118 clones, planted in 2002. Tapping began on panel BO-1 with $\mathrm{S} / 2$ d3 ET2.5\%. The frequency of stimulation was applied with variationsto each clone according to latex diagnosis which resulted before treatment. The result showed that the optimum frequency of stimulation was different in each clone. Optimum yield of IRR 24 and IRR 100 clones was achieved in unstimulation, stimulation increased the occurence of tapping panel dryness (TPD). Whereas, IRR 41, IRR 105, and IRR 118 clones were responsive to stimulant. The condition was supported by metabolism capacity and latex sucrose content before stimulation. The limiting factor for increasing yield was the sucrose content unstimulation and the plant ability to activate metabolism.
\end{abstract}

Keywords : Clone; ethephon; inorganic phosporus; sucrose; tapping panel dryness; yield

\begin{abstract}
Abstrak
Stimulan telah umum digunakan pada perusahaan perkebunan untuk mengoptimalkan tenaga kerja dan produksi. Aplikasi stimulan dapat meningkatkan lama aliran lateks dan metabolisme sel lateks. Namun aplikasi stimulan etefon seringkali tidak sesuai dengan kemampuan tanaman. Penerapan etefon stimulan dalam sistem eksploitasi hendaknya sesuai dengan tipologi klon. Tujuan penelitian ini adalah untuk mengetahui frekuensi stimulan yang optimal pada masing-masing klon dengan memperhatikan kondisi fisiologis dan kesehatan tanaman. Penelitian dilaksanakan di Kebun Percobaan Balai Penelitian Sembawa mulai 2011 hingga 2014, menggunakan klon IRR 24, IRR 41, IRR 100, IRR 105, dan IRR 118, tahun tanam 2002. Penyadapan mulai dilakukan pada panel B0-1 dengan sistem sadap $\mathrm{S} / 2 \mathrm{~d} 3$ ET2,5\%. Frekuensi stimulan diaplikasikan berbeda-beda pada setiap klon sesuai dengan hasil analisis lateks sebelum perlakuan. Hasil penelitian menunjukkan frekuensi stimulan yang optimum untuk tiap klon berbeda-beda. Produksi optimal pada IRR 24 dan IRR 100 dicapai pada kondisi tanpa stimulan, stimulan justru meningkatkan risiko kering alur sadap (KAS). IRR 41, IRR 105, dan IRR 118 respon terhadap stimulan. Kondisi tersebut didukung dengan kapasitas metabolisme dan kadar sukrosa lateks sebelum stimulan. Faktor pembatas peningkatan produksi adalah kadar sukrosa tanpa stimulan dan kemampuan tanaman dalam mengaktifkan metabolisme.
\end{abstract}


Kata kunci : Etefon; fosfat anorganik; kering alur sadap; klon; produksi; sukrosa

\section{PENDAHULUAN}

Secara umum prinsip pemanenan tanaman karet adalah untuk mendapatkan produksi maksimal dan berkesinambungan. Artinya tanaman karet diharapkan mampu mengeluarkan lateks secara terus-menerus tanpa mengalami gangguan. Gangguan yang umum terjadi yaitu tidak keluarnya lateks saat dilakukan penyadapan yang sering disebut dengan istilah kering alur sadap (KAS). Salah satu faktor yang memicu terjadi KAS adalah penggunaan stimulan yang berlebihan. Aplikasi stimulan telah lama diterapkan pada perkebunan karet untuk mengoptimalkan keuntungan. Salah satu keuntungan penggunaan stimulan adalah penurunan frekuensi sadap sehingga dengan produktivitas yang sama, tenaga kerja lebih efisien.

Mekanisme kerja stimulan telah banyak dipelajari di antaranya dapat meningkatkan lamanya aliran lateks dan metabolisme sel lateks (Gohet et al., 2008; Tungngoen et al., 2009; Lacote et al., 2010; Krishnakumar et al., 2011). Stimulan mempengaruhi kadar sukrosa dan fosfat anorganik (Pi) dalam lateks (Nguyen et al., 2016). Hubungan antara frekuensi stimulan dengan kadar sukrosa lateks mempunyai pola hiperbolik, artinya dengan peningkatan frekuensi stimulan akan meningkatkan konsumsi sukrosa lateks. Sebaliknya kadar Pi lateks mempunyai hubungan parabolik, yaitu pada kondisi telah mencapai level maksimum, peningkatan frekuensi stimulan tidak diikuti dengan peningkatan Pi lateks (Gohet, Regis, Franck, Thierry, \& Antoine, 2011). Disamping efek positif, stimulan etefon juga dapat memberikan efek negatif jika dalam aplikasinya berlebihan. Hasil penelitian Herlinawati dan Kuswanhadi (2013) serta Putranto et al. (2015) menyatakan bahwa aplikasi etefon yang berlebihan meningkatkan risiko KAS.

Konsep tipologi klon telah diterapkan oleh Gohet et al. (2003) dan Lacote et al. (2013), yang didasarkan pada kondisi awal aktivitas metabolisme dan kapasitas sukrosa pada masing-masing klon. Tipologi klon diharapkan dapat digunakan untuk menentukan sistem eksploitasi yang tepat dan memprediksi potensi produksi sesuai dengan kemampuan tanaman. Pada klon dengan kapasitas sukrosa yang tinggi dan Pi rendah maka intensitas stimulasi dapat ditingkatkan, begitu juga sebaliknya. Tujuan penelitian ini adalah untuk mengetahui frekuensi stimulan yang optimal pada masing-masing klon dengan memperhatikan kondisi fisiologis dan kesehatan tanaman.

\section{BAHAN DAN METODE}

Penelitian dilaksanakan di Kebun Percobaan Balai Penelitian Sembawa, Palembang mulai Agustus 2011 hingga Desember 2014. Kondisi agroklimat penelitian mempunyai rata-rata temperatur $22,64-31,79^{\circ} \mathrm{C}$ dan curah hujan 2.644 $\mathrm{mm} /$ tahun. Penelitian disusun berdasarkan Rancangan Acak Kelompok dengan tiga ulangan. Tiap plot terdiri atas lima belas pohon. Penelitian menggunakan klon IRR 24, IRR 41, IRR 100, IRR 105, dan IRR 118 tahun tanam 2002 yang ditanam dengan jarak tanam $6 \mathrm{~m} \times 3 \mathrm{~m}$. IRR 24 dan IRR 41 termasuk klon yang mempunyai kadar $\mathrm{Pi}$ dan sukrosa rendah. IRR 100 memiliki kadar $\mathrm{Pi}$ dan sukrosa medium. IRR 105 mempunyai kadar Pi tinggi dan sukosa rendah. Sedangkan IRR 118 mempunyai kadar Pi tinggi dan sukrosa yang medium (Kuswanhadi, Sumarmadji, Karyudi \& Siregar, 2009). Perlakuan yang digunakan adalah frekuensi stimulan dengan jumlah frekuensi berbeda-beda antar klon sesuai dengan hasil analisis lateks sebelum dilakukan penelitian. Kadar sukrosa dan Pi sebelum perlakuan disajikan pada Tabel 1 . Selain itu perbedaan frekuensi stimulan antar klon disebabkan adanya keterbatasan pohon sampel. Frekuensi stimulan untuk masing-masing klon adalah sebagai berikut:

IRR $24: 0 / \mathrm{y}, 10 / \mathrm{y}, 20 / \mathrm{y}$

IRR $41:$ :0/y, $1 / \mathrm{y}, 5 / \mathrm{y}, 10 / \mathrm{y}, 20 / \mathrm{y}$

IRR $100: 0 / \mathrm{y}, 1 / \mathrm{y}, 2 / \mathrm{y}, 3 / \mathrm{y}, 4 / \mathrm{y}, 6 / \mathrm{y}$

IRR $105: 0 / y, 1 / y, 2 / y, 3 / y, 4 / y$

IRR $118: 0 / \mathrm{y}, 5 / \mathrm{y}, 10 / \mathrm{y}, 20 / \mathrm{y}, 40 / \mathrm{y}$ 
Tabel 1. Klasifikasi klon berdasarkan sukrosa dan Pi sebelum perlakuan

Table 1.Clone classification based on the sucrose and Pi content before treatment

\begin{tabular}{|c|c|c|c|}
\hline \multirow{2}{*}{$\begin{array}{l}\text { Sukrosa } \\
\text { Sucrose }\end{array}$} & \multicolumn{3}{|c|}{$\begin{array}{l}\text { Fosfat anorganik (Pi) } \\
\text { Inorganic phosporus }\end{array}$} \\
\hline & $\begin{array}{l}\text { Rendah } \\
\text { Low }\end{array}$ & $\begin{array}{l}\text { Medium } \\
\text { Medium } \\
\end{array}$ & $\begin{array}{l}\text { Tinggi } \\
\text { High }\end{array}$ \\
\hline $\begin{array}{c}\text { Rendah } \\
\text { Medium } \\
\text { Tinggi }\end{array}$ & IRR 41 & $\begin{array}{c}\text { IRR 105, IRR 100, IRR } 24 \\
\text { IRR } 118\end{array}$ & \\
\hline
\end{tabular}

Pengukuran Parameter

1. Produksi karet ditimbang sebagai lateks dan lump mangkok, dilakukan setiap hari sadap. Produksi lateks tanpa stimulan dinotasikan dengan $\mathrm{P}_{0}$.

2. Kadar karet kering (KKK) lateks diukur dengan menggunakan Metode Chee dengan rumus sebagai berikut (Solichin, Suwardin \& Vachlepi, 2012 ). Pengeringan lateks dilakukan dengan oven suhu $100^{\circ} \mathrm{C}$ hingga bobotnya tetap.

$\mathrm{KKK}=\frac{B K}{B B} \times \mathrm{FK} \times 100 \%$

Dimana (Remaks) :

$\mathrm{BK}=$ berat kering

$\mathrm{BB}=$ berat basah

$\mathrm{FK}=$ faktor koreksi $(0,72)$

3. Lateks diagnosis dilakukan pada bulan maksimum yaitu April-Mei. Kadar sukrosa dan fosfat anorganik dianalisis dengan menggunakan Spektrofotometer pada panjang gelombang 627 dan 750 $\mathrm{nm}$. Setiap sampel lateks diambil sebanyak $1 \mathrm{ml}$ dicampur dengan $9 \mathrm{ml}$ TCA 2,5\% (Tricloroacetic acid) untuk memisahkan serum C. Kadar sukrosa dianalisis dengan menggunakan metode Anthrone (Dische, 1962). Kadar fosfat anorganik ditentukan berdasarkan pengikatan oleh ammonium molibdat yang kemudian tereduksi oleh $\mathrm{FeSO}_{4}$ dalam reaksi asam (Taussky \& Shorr, 1953). Kadar sukrosa dan kadar fosfat anorganik tanpa stimulan dinotasikan dengan Suc $_{0}$ dan $\mathrm{Pi}_{0}$.
4. Persentase kering alur sadap (KAS) dilakukan secara visual dan diubah dengan penilaian persentase yaitu tidak ada KAS $(0 \%), 1-25 \%$ alur sadap kering, $26-50 \%$ alur sadap kering, $51-75 \%$ alur sadap kering, dan $76-100 \%$ alur sadap kering.

Pengolahan Data

Data dianalisis dengan menggunakan perangkat lunak Statistical Analysis System (SAS) dan dilanjutkan dengan menggunakan Uji Jarak Berganda Duncan pada taraf kepercayaan $5 \%$.

\section{HASIL DAN PEMBAHASAN}

\section{Kondisi Agroklimat}

Kondisi curah hujan dan hari hujan selama penelitian disajikan pada Gambar 1 . Total curah hujan mencapai lebih dari 2000 $\mathrm{mm} /$ tahun pada tahun 2011, 2012, dan 2013. Namun tahun 2014, curah hujan mengalami penurunan. Pola yang sama juga terjadi pada hari hujan/tahun. Disamping itu pada tahun 2013, tidak terjadi bulan kering, sebaliknya tahun 2014 terjadi bulan kering pada bulan Februari, September dan Oktober (curah hujan $<50 \mathrm{~mm} /$ bulan). Kondisi agroklimat dapat mempengaruhi fisiologi, pertumbuhan dan produksi tanaman karet (Wijaya, 2015; Gohet et al., 2015). Besarnya peningkatan produksi akibat penggunaan stimulan sangat dipengaruhi oleh kondisi lingkungan penelitian. 


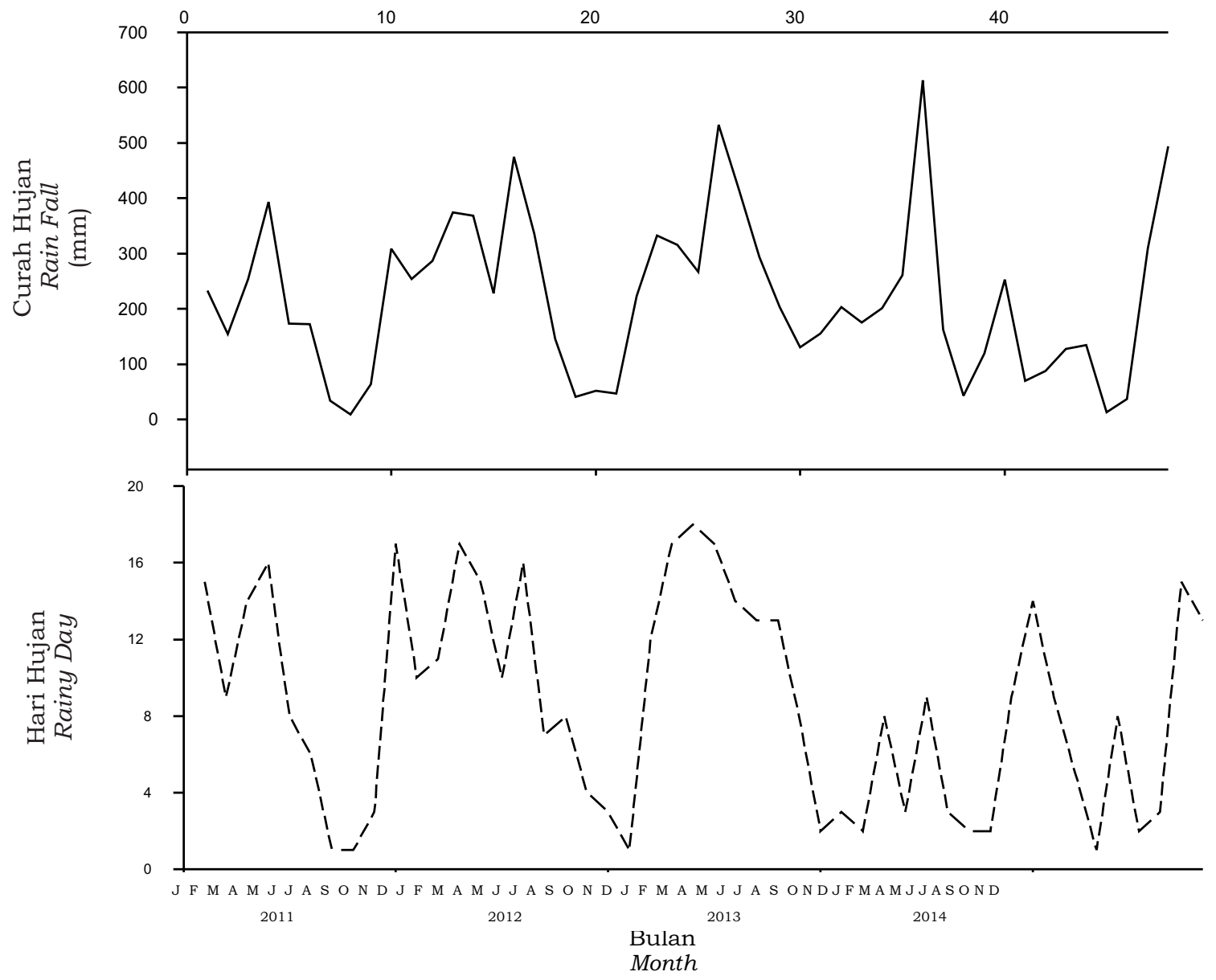

Gambar 1. Kondisi curah hujan dan hari hujan tahun 2011-2014.

Figure 1. Condition of rainfall and rainy day from 2011-2014.

\section{Karakter Klon Tanpa Stimulan}

Produksi tertinggi hingga terendah pada kondisi tanpa stimulan $\left(\mathrm{P}_{0}\right)$ yaitu IRR 24, IRR 100, IRR 105, IRR 118, dan IRR 41 (Tabel 2). IRR 24 dan IRR 100 mempunyai sukrosa yang rendah $\left(\mathrm{Suc}_{0}\right)$ dibandingkan dengan klon yang lain. Sedangkan IRR 105, IRR 118, dan IRR 41 mempunyai kadar sukrosa yang lebih besar berkisar 5-7 mM. Kadar Pi pada IRR 24 paling besar dibandingkan dengan klon yang lain $\left(\mathrm{Pi}_{0}\right)$. Sebaliknya IRR 41 memiliki kadar Pi yang paling rendah. IRR 100 dan IRR 118 mempunyai kadar Pi medium.
Hubungan antara $P_{0}$ dengan Suc pada berbagai klon menunjukkan korelasi yang negatif sebesar $r=-0,351$ (Gambar 2a). Produksi tinggi akan diikuti dengan kadar sukrosa rendah. Sedangkan hubungan antara $\mathrm{P}_{0}$ dengan $\mathrm{Pi}_{0}$ mempunyai korelasi positif $(r=0,736)$ (Gambar 2b). Pada umumnya produksi tinggi akan diikuti dengan peningkatan metabolisme tanaman (Phearun et al., 2016). 
Tabel 2. Rata-rata produksi lateks $\left(\mathrm{P}_{0}\right)$, kadar sukrosa $\left(\mathrm{Suc}_{0}\right)$, kadar fosfat anorganik $\left(\mathrm{Pi}_{0}\right)$ tanpa stimulan pada berbagai klon.

Table 2. Average latex yield $\left(P_{o}\right)$, sucrose $\left(\mathrm{Suc}_{0}\right)$, inorganic phosporus $\left(\mathrm{Pi}_{0}\right)$ unstimulation in each clone.

\begin{tabular}{cccc}
\hline Klon & Po & Pi $_{0}$ & Suc $_{0}$ \\
Clone & $32,23 \mathrm{a}$ & $23,71 \mathrm{a}$ & $2,74 \mathrm{~b}$ \\
IRR 24 & $14,93 \mathrm{~d}$ & $5,94 \mathrm{~b}$ & $5,34 \mathrm{ab}$ \\
IRR 41 & $31,77 \mathrm{a}$ & $15,68 \mathrm{a}$ & $3,07 \mathrm{~b}$ \\
IRR 100 & $27,65 \mathrm{~b}$ & $19,40 \mathrm{a}$ & $7,20 \mathrm{a}$ \\
IRR 105 & $23,83 \mathrm{c}$ & $14,84 \mathrm{a}$ & $6,84 \mathrm{a}$ \\
\hline IRR 118 &
\end{tabular}

Keterangan : Angka yang diikuti huruf sama pada kolom sama menunjukkan tidak beda nyata pada taraf signifikasi $5 \%$

Remaks: Values followed by the same letter in the same column, were not significantly different at 5\%
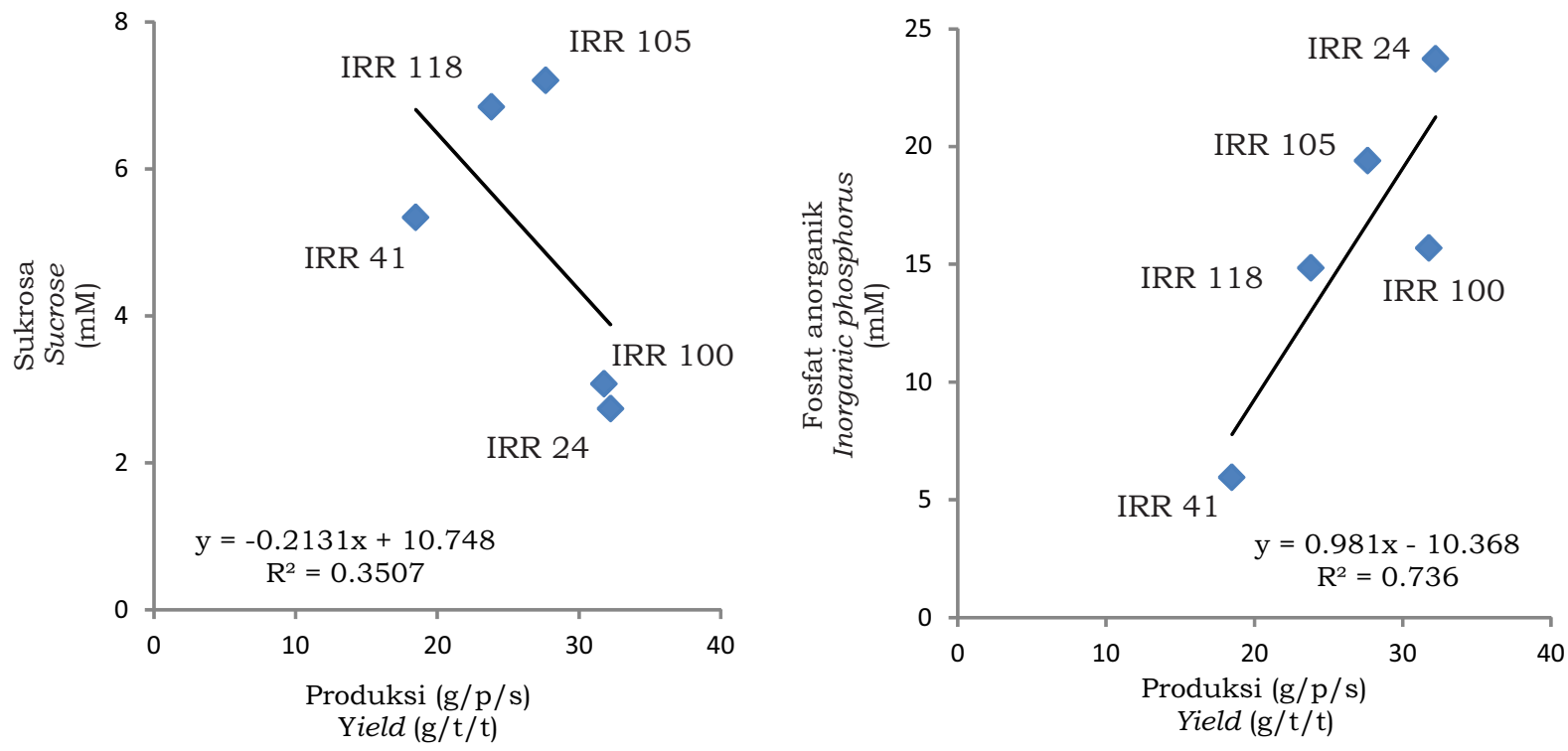

Gambar 2. Hubungan antara produksi tanpa stimulan dengan kadar sukrosa (a) dan kadar fosfat anorganik (b).

Figure 2. Relationship between yield without stimulation with sucrose content (a) and inorganic phosporus content (b).

\section{Pengaruh Stimulan Etefon}

Tiap klon mempunyai frekuensi optimum stimulan yang berbeda-beda sesuai dengan karakter fisiologi. IRR 41 dan IRR 118 mempunyai respon baik terhadap stimulan, produksi maksimum tercapai pada stimulan sebanyak 20/y (Tabel 3). IRR 105 memiliki respon rendah, ditandai dengan Pmax pada 3/y. Sedangkan IRR 24 dan IRR 100 tidak respon terhadap stimulan sehingga mempunyai produksi optimal pada kondisi tanpa stimulan. Selisih antara produksi tanpa stimulan dengan produksi optimum bervariasi antar klon $(\Delta \mathrm{P}=\mathrm{Pmax}$ $\mathrm{P}_{0}$ ). $\Delta \mathrm{P}$ tertinggi dicapai oleh IRR 41 sebesar 13,4. IRR 24 dan IRR 100 mempunyai $\Delta \mathrm{P}$ sama dengan nol. Sedangkan IRR 118 dan IRR 105 mempunyai $\Delta \mathrm{P}$ sebesar 10,79 dan 3,3 . 
Tabel 3. Rata-rata produksi lateks selama 4 tahun.

Table 3. Average latex yield during 4 years.

\begin{tabular}{|c|c|c|c|c|c|}
\hline \multirow{2}{*}{$\begin{array}{l}\text { Jumlah stimulasi per tahun } \\
\text { Number of stimulations per year }\end{array}$} & \multicolumn{5}{|c|}{$\begin{array}{l}\text { Rata-rata produksi lateks pada klon }(\mathrm{g} / \mathrm{p} / \mathrm{s}) \\
\text { Average latex yield on clone }(\mathrm{g} / \mathrm{t} / \mathrm{t})\end{array}$} \\
\hline & IRR 24 & IRR 41 & IRR 100 & IRR 105 & IRR 118 \\
\hline $0 / y$ & $32,23 \mathrm{tn}$ & $18,49 \mathrm{c}$ & $31,77 \mathrm{tn}$ & $27,65 \mathrm{~b}$ & $23,83 \mathrm{c}$ \\
\hline $1 / y$ & & $19,78 \mathrm{c}$ & 30,50 & $28,15 \mathrm{~b}$ & \\
\hline $2 / y$ & & & 27,52 & $29,21 \mathrm{ab}$ & \\
\hline $3 / y$ & & & 29,99 & 30,98 a & \\
\hline $4 / y$ & & & & $31,25 \mathrm{a}$ & \\
\hline $5 / y$ & & $23,62 \mathrm{~b}$ & & & $30,19 \mathrm{~b}$ \\
\hline $6 / y$ & & & 30,84 & & \\
\hline $10 / y$ & 31,29 & $24,83 \mathrm{~b}$ & & & $29,98 \mathrm{~b}$ \\
\hline $20 / y$ & 32,24 & $31,89 a$ & & & 34,62 a \\
\hline $40 / y$ & & & & & $36,22 \mathrm{a}$ \\
\hline$\Delta \mathrm{P}=$ Pmax $-\mathrm{PO}$ & 0 & 13,4 & 0 & 3,3 & 10,79 \\
\hline
\end{tabular}

Keterangan : Angka yang diikuti huruf sama pada kolom sama menunjukkan tidak beda nyata pada taraf signifikasi $5 \%$

Remaks : values followed by the same letter in the same column, were not significantly different at 5\%

Dari aspek fisiologi, IRR 24 memiliki Pi paling tinggi pada kondisi tanpa stimulan (Tabel 4). Kadar Pi dengan penambahan frekuensi hingga 20/y menunjukkan tidak berbeda nyata. Sebaliknya penambahan stimulan pada klon IRR 100, IRR 118, IRR 41, dan IRR 105 meningkatkan kadar $\mathrm{Pi}$ lateks. Selisih kadar Pi tanpa stimulan dengan pemberian stimulan disimbolkan dengan $(\Delta \mathrm{Pi})$ yang berbeda-beda antar klon. IRR 118 mempunyai $\Delta \mathrm{Pi}$ tertinggi, sedangkan IRR 41 dan IRR 105 mempunyai $\Delta$ Pi berkisar 8,41 $\mathrm{mM}$ dan 5,91 $\mathrm{mM}$.

Tabel 4. Rata-rata fosfat anorganik selama 4 tahun.

Table 4. Average inorganic phospourus during 4 years.

\begin{tabular}{|c|c|c|c|c|c|}
\hline \multirow[t]{2}{*}{$\begin{array}{l}\text { Jumlah stimulasi per tahun } \\
\text { Number of stimulations per year }\end{array}$} & \multicolumn{5}{|c|}{$\begin{array}{l}\text { Rata-rata fosfat anorganik pada klon } \\
\text { Average inorganic phospourus on clone } \\
\text { (mM) }\end{array}$} \\
\hline & IRR 24 & IRR 41 & IRR 100 & IRR 105 & IRR 118 \\
\hline $0 / y$ & $23,71 \mathrm{tn}$ & $5,94 \mathrm{~b}$ & $15,69 \mathrm{~b}$ & $19,40 \mathrm{tn}$ & $14,84 \mathrm{~b}$ \\
\hline $1 / \mathrm{y}$ & & $10,15 \mathrm{ab}$ & $16,99 \mathrm{ab}$ & 23,40 & \\
\hline $2 / \mathrm{y}$ & & & $23,77 \mathrm{ab}$ & 24,20 & \\
\hline $3 / y$ & & & $19,39 \mathrm{ab}$ & 25,31 & \\
\hline $4 / y$ & & & & 25,57 & \\
\hline $5 / y$ & & $7,25 \mathrm{~b}$ & & & $19,46 \mathrm{ab}$ \\
\hline $6 / y$ & & & $24,34 \mathrm{a}$ & & \\
\hline $10 / y$ & 22,96 & $10,46 \mathrm{ab}$ & & & $19,58 \mathrm{ab}$ \\
\hline $20 / y$ & 26,64 & $14,35 \mathrm{a}$ & & & 27,81 ab \\
\hline $40 / \mathrm{y}$ & & & & & $21,38 \mathrm{a}$ \\
\hline$\Delta \mathrm{Pi}=\mathrm{P}_{\max }-\mathrm{P}_{0}$ & 0 & 8,41 & 0 & 5,91 & 12,97 \\
\hline
\end{tabular}

Keterangan : Angka yang diikuti huruf sama pada kolom sama menunjukkan tidak beda nyata pada taraf signifikasi $5 \%$

Remaks : values followed by the same letter in the same column, are not significantly different at 5\%

Untuk kadar sukrosa lateks, pemberian stimulan pada IRR 24 dan IRR 100 tidak mampu meningkatkan konsumsi sukrosa (Tabel 5). Pemberian stimulan pada IRR 41 dan IRR 118 menunjukkan tidak berbeda nyata, namun mempunyai kecenderungan peningkatan konsumsi sukrosa. Konsumsi sukrosa tertinggi terjadi pada klon IRR 118. Pemberian stimulan pada IRR 105 meningkatkan konsumsi sukrosa secara signifikan. 
Tabel 5. Rata-rata kadar sukrosa selama 4 tahun.

Table 5. Average sucrose content during 4 years.

\begin{tabular}{|c|c|c|c|c|c|}
\hline \multirow[t]{2}{*}{$\begin{array}{l}\text { Jumlah stimulasi per tahun } \\
\text { Number of stimulations per year }\end{array}$} & \multicolumn{5}{|c|}{$\begin{array}{l}\text { Rata-rata kadar sukrosa pada klon } \\
\text { Average sucrose content on clone } \\
(\mathrm{mM})\end{array}$} \\
\hline & IRR 24 & IRR 41 & IRR 100 & IRR 105 & IRR 118 \\
\hline $0 / y$ & 2,74 tn & $5,34 \mathrm{tn}$ & $3,07 \mathrm{tn}$ & $7,20 \mathrm{a}$ & $6,84 \mathrm{tn}$ \\
\hline $1 / y$ & & 5,19 & 4,25 & $3,42 \mathrm{~b}$ & \\
\hline $2 / y$ & & & 2,76 & $4,32 \mathrm{~b}$ & \\
\hline $3 / y$ & & & 3,09 & $4,86 a b$ & \\
\hline $4 / y$ & & & & $5,04 a b$ & \\
\hline $5 / y$ & & 4,41 & & & 6,76 \\
\hline $6 / y$ & & & 3,29 & & \\
\hline $10 / y$ & 2,82 & 3,55 & & & 7,41 \\
\hline $20 / y$ & 2,24 & 2,65 & & & 3,79 \\
\hline $40 / y$ & & & & & 6,53 \\
\hline$\Delta \mathbf{S u c}=\mathbf{S u c}_{0}-\mathbf{S u c}_{\max }$ & 0 & 2,69 & 0 & 2,34 & 3,05 \\
\hline
\end{tabular}

Keterangan : Angka yang diikuti huruf sama pada kolom sama menunjukkan tidak beda nyata pada taraf signifikasi $5 \%$

Remaks : values followed by the same letter in the same column, are not significantly different at $5 \%$

Pemberian stimulan pada IRR 100 meningkatkan metabolisme tanaman, namun kondisi tersebut tidak didukung dengan kadar sukrosa yang berada pada level minimum. Oleh sebab itu kadar sukrosa merupakan salah satu faktor pembatas tidak responnya IRR 100 terhadap stimulan. Potensi produksi disetiap klon ditentukan oleh kadar sukrosa pada kondisi tanpa stimulan dan juga kemampuan klon dalam mengaktifkan metabolisme (Gohet et al., 1997 ; Lacote et al., 2013). Sebagai ilustrasi kadar Pi pada IRR 100 sebesar 15,69 mM dan IRR 118 sebesar 14,84 mM (Gambar 3) ternyata memiliki potensi peningkatan produksi yang berbeda. Hal ini ditentukan oleh kadar sukrosa pada masingmasing klon. Stimulan pada IRR 118 mampu meningkatkan metabolisme karena tersedianya sukrosa yang akan diubah menjadi lateks. Sedangkan pada IRR 100, stimulan tidak mampu meningkatkan $\mathrm{Pi}$ karena kadar sukrosa sudah pada level rendah.

Sebaliknya pada IRR 105, kadar Pi sudah mencapai maksimum namun kadar sukrosa lateks masih dapat dioptimalkan dengan pemberian stimulan. Untuk IRR 24, kadar Pi maupun sukrosa lateks tidak dapat ditingkatkan dengan adanya penambahan stimulan. Kondisi tersebut terjadi karena

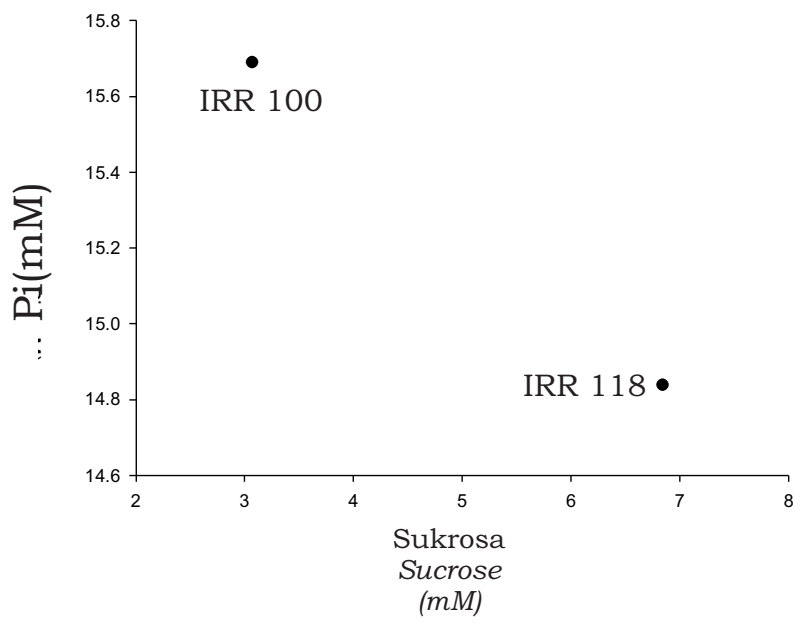

Gambar 3. Perbandingan kadar Pi dan sukrosa antara IRR 100 dan IRR 118.

Figure 3. Comparison inorganic phosphorus and sucrose content between IRR 100 and IRR 118 . 
kadar Pi sudah mencapai maksimum dan kadar sukrosa lateks sudah mencapai batas minimum. Sedangkan efek aplikasi stimulan pada IRR 118 dan IRR 41 berjalan simultan antara kadar Pi dengan sukrosa lateks yaitu Pi lateks menjadi meningkat sehingga meningkatkan konsumsi sukrosa lateks yang masih dapat dioptimalkan.

Kondisi peningkatan produksi dengan penambahan stimulan perlu dipertimbangan dengan melihat faktor kesehatan tanaman. Pada IRR 24 dan IRR 100 optimal pada kondisi tanpa stimulan karena dengan penambahan stimulan akan meningkatkan skor KAS (Tabel 6). Pada umumnya dengan penambahan stimulan memiliki kecenderungan terjadi peningkatan persentase KAS. Pemberian stimulan yang melebihi batas kemampuan tanaman akan memicu tidak berfungsinya sel lateks (Lacote et al., 2010).

Tabel 6. Intensitas KAS selama 4 tahun

Table 6. Intensity of dry cut length during 4 years

\begin{tabular}{|c|c|c|c|c|c|}
\hline \multirow[t]{2}{*}{$\begin{array}{l}\text { Jumlah stimulasi per tahun } \\
\text { Number of stimulations per year }\end{array}$} & \multicolumn{5}{|c|}{$\begin{array}{c}\text { Intensitas KAS pada klon } \\
\text { Tapping pannel dryness on clone } \\
(\%)\end{array}$} \\
\hline & IRR 24 & IRR 41 & IRR 100 & IRR 105 & IRR 118 \\
\hline $0 / y$ & 3,42 & 31,00 & 27,33 & 27,33 & 6,67 \\
\hline $1 / \mathrm{y}$ & & 42,00 & 0,67 & 28,00 & \\
\hline $2 / y$ & & & 12,00 & 21,67 & \\
\hline $3 / y$ & & & 26,00 & 34,00 & \\
\hline $4 / y$ & & & & 35,33 & \\
\hline $5 / y$ & & 52,00 & 35,67 & & 0,33 \\
\hline $6 / y$ & & & & & \\
\hline $10 / y$ & 21,33 & 23,00 & & & 18,00 \\
\hline $20 / y$ & 11,67 & 6,33 & & & 32,67 \\
\hline $40 / y$ & & & & & 29,00 \\
\hline
\end{tabular}

\section{KESIMPULAN}

Aplikasi penggunaan stimulan harus didasarkan pada kondisi fisiologis (kadar fosfat anorganik dan kadar sukrosa) dan kesehatan tanaman. Produksi optimal IRR 24 dan IRR 100 dicapai pada kondisi tanpa stimulan, stimulan justru meningkatkan risiko KAS. IRR 41, IRR 105, dan IRR 118 respon terhadap stimulan. Kondisi tersebut didukung dengan kapasitas metabolisme dan kadar sukrosa lateks yang belum optimal sebelum dilakukan stimulan. Faktor pembatas peningkatan produksi adalah kadar sukrosa tanpa stimulan dan kemampuan tanaman mengaktifkan metabolisme.

\section{DAFTAR PUSTAKA}

Dische, Z.M. (1962). Methods in Carbohydrate Chemistry. New York, US : Academic Press
Gohet, E., Dian, K., Prevot, J.C., Obouayeba, S., Keli, J.Z., d'Auzac, J., \& Jacob, J.L. (1997). The relationship between latex sugar content, the metabolic activity of the latex-bearing system and the production potensial of Hevea brasiliensis clones. Symposium on Natural Rubber (Hevea Brasiliensis) : Vol. II-Physiology and Exploitation and Crop Protecction an Planting Methods Seccions. Ho Chi Minh City, Vietnam : IRRDB.

Gohet, E., Chantuma, P., Lacote, R., Obouayeba, S., Dian, K., ClementDemange, A., Kurnia, D., \& Eschbach, J.M. (2003). Latex clonal typology of Hevea brasiliensis : physiologycal modelling of yield potential and clonal response to ethephon stimulation. IRRDB Workshop on Exploitation Technology (p. 199-216). Kottayam, India: IRRDB. 
Gohet, E., Somparin, C., Cavalog, E., Balerin, Y., Benites, G., Dumortier, F., Williams, H., Permadi, H.P., Ginting, E., De Rostolan, E., Uche, E., Chegbene, P., Hocepied, E., Echimane, P., Saumahoro, M., Sargeant, H.J., Suyatno, Najera, C.A., Saumahoro, B., Lacote, R., \& Eschbach, J.M. (2008). Influence of ethephon stimulation on latex physiological parameter and conquences on latex diagnosis implementation in rubber agroindustry. IRRDB Workshop on Latex Harvesting Technology (12p.). Selangor, Malaysia : IRRDB. Doi : 10.13140/RG.2.1.1397.7127

Gohet, E., Lacote, R., Rivano, F., Chapuset, T., \& Leconte, A. (2011). Influence of ethephon stimulation on latex physiological parameters and consequences on latex diagnosis implementation in rubber agroindustry. Proceedings of the XI Jornadas Latinoamericanas del caucho natural. Medellin, Colombia : $\mathrm{J}$ o r n a d a s. D o i 10.13140/RG.2.1.2886.6089.

Gohet, E., Thaler, P., Rivano, F., Chapuset, T., Gay, F., Chantuma, P., \& Lacote, R. (2015). A tentative composite climate index to predict and quantify the effect of climate on natural rubber yield potential. Proceedings of the International Rubber Conference 2015. Ho Chi Minh City, Vietnam : RRIVIRRDB.

Herlinawati, E., \& Kuswanhadi. (2013). Aktifitas metabolisme beberapa klon karet pada berbagai frekuensi sadap dan stimulasi. Jurnal Penelitian Karet, 31 ( 2), $110-116$. D o i : 10.22302/ppk.jpk.v31i2.138

Krishnakumar, R., Helen, R.L., Ambily, P. K., \& Jacob, J. (2011). A modified stimulation method in Hevea brasiliensis for reducing oxidative stress. IRRDB International Rubber Conference. Bangkok, Thailand : IRRDB.
Kuswanhadi., Sumarmadji., Karyudi., \& Siregar, T.H.S. (2009). Optimasi produksi klon karet melalui sistem eksploitasi berdasarkan metabolisme lateks. Lokakarya Nasional Pemuliaan Tanaman Karet 2009. Batam, Indonesia : Pusat Penelitian Karet.

Lacote, R., Gabla, O., Obouayeba, S., Eschbach, J.M., Rivano, F., Dian, K., \& Gohet, E. (2010). Long term effect of ethylene stimulation on the yield of rubber trees is linked to latex cell biochemistry. Field Crops Research, $115(1), 94-98$. D o i: $10.1016 /$ j.fcr.2009.10.007

Lacote, R., Doumbia, A., Obouayeba, S., \& Gohet, E. (2013). Sustainable rubber production through good latex harvesting practices: stimulation based on clonal latex functional typology and tapping panel management. IRRDB Workshop on Latex Harvesting Technology (18p.). RRIV Binh Duong, Vietnam: RRIVIRRDB

Nguyen, V.H.T., Diem, N.V.L., Thao, T.T.N., Thuy, T.K., Nang, N., \& Thanh, K.D. (2016). Seasonal variation and evolution of some latex physiological parameters of hevea brasiliensis over consecutive tapping years. Proceedings of the CRRI \& IRRDB International Rubber Conference 2016. Siem Reap, Cambodia : CRRI - IRRDB.

Phearun, P., Chetha, P., Bunthuon, H., Lacote, R., Chan, C., Sopheaveasna, M., \& Gohet, E. (2016). Early clonal selection of hevea brasiliensis based on latex physiological parameters in Cambodia. Proceedings of the CRRI \& IRRDB International Rubber Conference 2016. Siem Reap, Cambodia : CRRI IRRDB. 
Putranto, R.A., Herlinawati, E., Rio, M., Leclercq, J., Piyatrakul, P., Gohet, E., Sanier, C., Oktavia, F., Pirrello, J., Kuswanhadi., \& Montoro, P. (2015). Involvement of ethylene in the latex metabolism and tapping panel dryness of Hevea brasiliensis. International Journal of Molecular Sciences, 16(8), $17885-17908$. $10.3390 / \mathrm{ijms} 160817885$

Solichin, M., D. Suwardin, dan A. Vachlepi. 2012. Saptabina Usahatani Karet Rakyat : Pengolahan. Balai Penelitian Sembawa-Pusat Penelitian Karet. 105114.

Taussky, H.H., \& Shorr, E. (1953). A micro colorimetric methods for the determination of inorganic phosphorus. Journal of Biological Chemistry, 202, 675-685.
Tungngoen, K., Kongsawadworakul, P. Viboonjun, U., Katsuhara, M., Brunel, N., Sakr, S., Narangajavana, J., \& Chrestin, H. (2009). Involvement of HbP1P2;1 dan HbT1P1;1 aquaporins in ethylene stimulation of latec yield, through regulation of water exchanges between inner liber and latex cells in Hevea brasiliensis. Plant Physiology, 151 ( 2) , 843-856. Do i: $10.1104 /$ pp. 109.140228

Wijaya, T. (2015). The utilization of climate data to support agronomic practices in rubber plantation. Proceeding International Rubber Conference 2015 (p. 131-138). Ho Chi Minh City, Vietnam: RRIV-IRRDB. 